\title{
First Record of the Giant Grouper Epinephelus lanceolatus (Perciformes: Serranidae: Epinephelinae) from Jeju Island, South Korea
}

\author{
Jung-Goo Myoung ${ }^{1}$, Chung-Bae Kang ${ }^{2, *}$, Jae Myung Yoo ${ }^{1}$, Eun Kyung Lee ${ }^{1}$, Sung Kim ${ }^{1}$, \\ Choong-Hoon Jeong ${ }^{3}$ and Byung-Il Kim ${ }^{4}$ \\ ${ }^{1}$ Marine Living Resources Research Department, Korea Institute of Ocean Science \& Technology, KIOST, Ansan 426-744, Korea \\ ${ }^{2}$ Korea Inter-University Institute of Ocean Science, Pukyong National University, Busan 608-737, Korea \\ ${ }^{3}$ Research Center for Coastal Environments of Yellow Sea (CCEYS), Inha University, Incheon 402-751, Korea \\ ${ }^{4}$ Pacific Diving School, Jeju 697-010, Korea
}

\begin{abstract}
A single specimen of Epinephelus lanceolatus, belonging to Epinephelinae of the family Serranidae, was newly collected from Jeju Island, South Korea, in December 2009. Epinephelus lanceolatus is characterized by anterior lateral-line scales with branched tubules, cycloid scales, irregular white spots, and fins with numerous small black spots. We propose a Korean name, "Dae-wangba-ri" for this species.
\end{abstract}

Key words: First record, Epinephelus lanceolatus, Serranidae, Epinephelinae, Jeju Island

\section{Introduction}

The giant grouper Epinephelus lanceolatus (also known as the Queensland grouper or Reef cod) is the largest species of the family Serranidae inhabiting the tropical and subtropical waters of all three major oceans (Heemstra and Randall, 1993). Approximately 522 species belonging to 73 genera and five subfamilies in Serranidae have been reported worldwide (Eschmeyer et al., 2010). Among the genera in the subfamily Epinephelinae, the genus Epinephelus comprises some 89 species (valid names) in marine habitats around the world (WoRMS, 2012). Epinephelus species are among the most important commercial fishes in the tropical fisheries of the world. They are among the highest priced species at fish markets, and a few species are used in aquaculture ventures (Heemstra and Randall, 1993). In South Korea, thirteen species of Epinephelus have been reported so far (Han et al., 2011).
Here, we report that a single specimen of E. lanceolatus was collected from Gang-jeong Port, Jeju Island, South Korea, for the first time. We describe the morphological characteristics of the species based on this specimen.

\section{Materials and Methods}

A single specimen of Epinephelus lanceolatus was collected form Gang-jeong Port, Jeju Island, South Korea, on 28 December 2009. The specimen was photographed while fresh and then preserved in $10 \%$ formalin. Counts and measurements followed Heemstra and Randall (1993). The examined specimen was deposited at the Korea Institute of Ocean Science and Technology (KIOST), Korea.
Open Access http://dx.doi.org/10.5657/FAS.2013.0049

This is an Open Access article distributed under the terms of the Creative Commons Attribution Non-Commercial License (http://creativecommons, org/licenses/by-nc/3.0/) which permits unrestricted non-commercial use, distribution, and reproduction in any medium, provided the original work is properly cited. pISSN: 2234-1749 eISSN: 2234-1757
Received 12 November 2012; Revised 24 December 2012

Accepted 24 December 2012

*Corresponding Author

E-mail: labrax@daum.net 


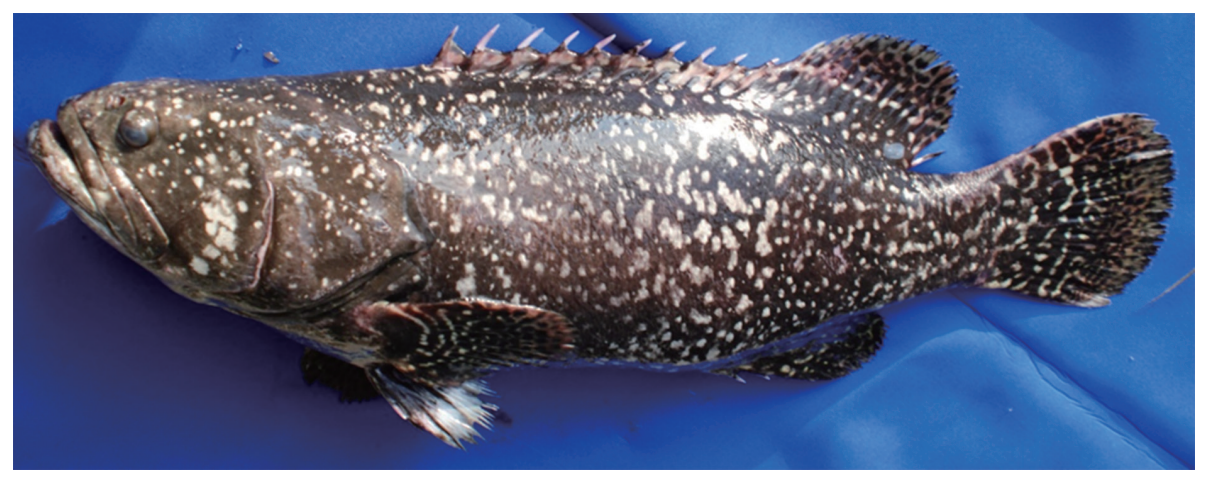

Fig. 1. Epinephelus lanceolatus, KIOST 20091228, 672 mm standard length.
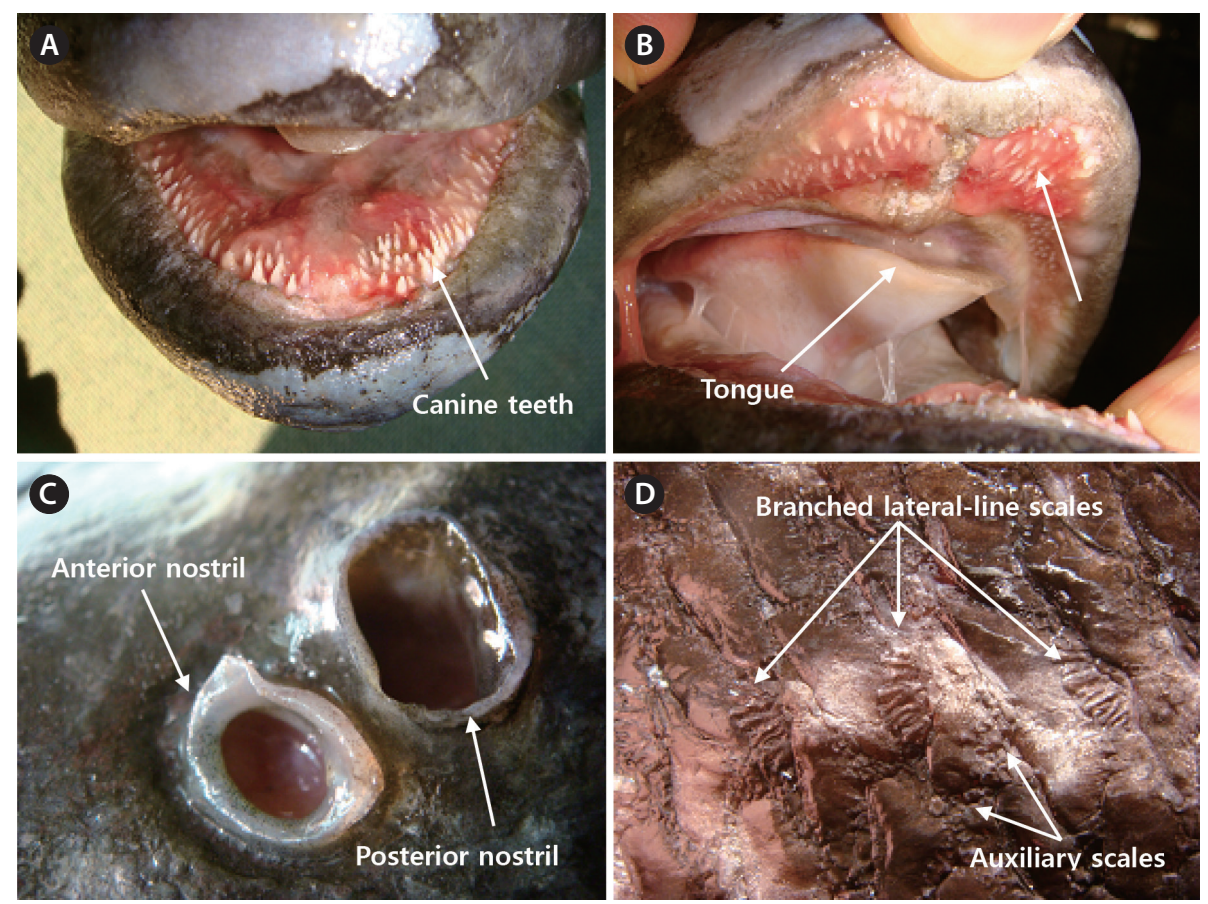

Fig. 2. A photograph showing jaws (A, B) and nostril (C), and lateral line of scales (D).

Table 1. Comparison of meristic characters of Epinephelus lanceolatus

\begin{tabular}{lcccc}
\hline & $\begin{array}{c}\text { Present } \\
\text { study }\end{array}$ & $\begin{array}{c}\text { Katayama } \\
\mathbf{( 1 9 8 4 )}\end{array}$ & $\begin{array}{c}\text { Randall and Heemstra } \\
(\mathbf{1 9 9 1 )}\end{array}$ & $\begin{array}{c}\text { Nakabo } \\
\mathbf{( 2 0 0 0 )}\end{array}$ \\
\hline No. of specimens & 1 & - & 43 & - \\
Standard length (mm) & 672 & & $30-1,770$ & XI, $14-16$ \\
Dorsal fin rays & XI, 14 & XI, 14-15 & III, 8 & XI, 14-16 \\
Anal fin rays & III, 8 & III, 8 & $18-20$ & III, 8 \\
Pectoral fin rays & 18 & 17 & & - \\
Ventral fin rays & I, 5 & - & $95-105$ & $86-110$ \\
Lateral scales series & 92 & $86-110$ & $54-62$ & $50-67$ \\
Lateral line scales & 55 & $50-60$ & $8-10+14-17$ & - \\
Gill rakers & $10+14$ & $10+15-16$ & & \\
\hline
\end{tabular}




\section{Material examined}

KIOST 20091228, one specimen, $672 \mathrm{~mm}$ in standard length (SL), Gang-jeong Port, Jeju Island, South Korea, 28 December 2009 , set net, $18 \mathrm{~m}$ depth, $17^{\circ} \mathrm{C}$ temperature, collected by Dr. Jung-Goo Myoung.

\section{Results and Discussion}

\section{Epinephelus lanceolatus (Bloch, 1790)}

(new Korean name: Dae-wang-ba-ri) (Table 1, Fig. 1)

Holocentrus lanceolatus Bloch, 1790: 92, p1. 242, fig. 1

(type locality: East Indies).

Serranus geopgraphicus: Cuvier and Valenciennes, 1828: 332 (type locality: Java).

Batrachus gigas: Günther, 1869: 131 (type locality: Seychelles). Oligorus terrae-reginae Ramsay, 1880: 93, pl. 9

(type locality: Queensland).

Promicrops lanceolatus: Katayama in Masuda et al., 1984: 132.

Serranus phaeostigmaeus: Fowler, 1907: 255, fig. 2

(type locality: Hawaiian Islands).

Epinephelus lanceolatus: Heemstra \& Randall, 1986: 526; 1993: 174; Randall \& Heemstra, 1991: 176; Kuiter, 1993: 132; Nakabo, 2002: 714; Konishi and Nakabo, 2007: 88.

\section{Description}

Counts are shown in Table 1. Proportions are given as \% of SL: body depth 31.8; head length (HL) 38.8; predorsal length 37.9 ; prepectoral length 29.0; preanal length 63.5 ; caudal peduncle length 13.9; caudal peduncle depth 14.4. Proportions given as \% of HL: eye diameter 9.8; interorbital width 28.3 ; upper jaw length 36.6; longest dorsal fin length 26.4; longest dorsal spine length 21.3; pectoral fin length 68.1; longest anal fin length 45.7 ; longest anal spine length 19.7; pelvic fin length 41.3.

Body elongate, subcylindrical and compressed. Mouth very large, posterior tip of maxilla reaches well past vertical at rear edge of eye. Interorbital space flat, the dorsal head profile slightly convex. Preopercle angular, finely serrate, the corner rounded, but no large antrose spines on ventral edge; upper edge of operclum convex. Two nostrils, sub-equal, posterior nostrils distinctly a bit wider than anterior nostrils (Fig. 2C). Mid-lateral portions of lower and upper jaws with 5-6 rows of canine teeth; tongue edentate (Fig. 2A and 2B). Dorsal fin spines shorter than rays; interspinous membranes of dorsal fin not incised, the 1 st to 10 th spines subequal, 11th (last) spine longest. Anal fin spines large; second is strongest. Pectoral fin, posterior ends of dorsal and anal fins, and caudal fin rounded. Pelvic fins not reaching anus. Lateral-body scales smooth cycloid; auxiliary scales present on body (Fig. 2D); anterior lateral-line scales with branched sensory tubules; very small scales on maxilla and snout.

\section{Color while fresh}

Dark gray-brown with scattered, with irregular whitish blotches and numerous small black spots, and fins slightly yellowish with irregular blackish and whitish markings.

\section{Distribution}

E. lanceolatus is distributed in the Indo-Pacific region, from South Africa to the Hawaiian Islands (Heemsta and Randall, 1993), Japan, South China, the Philippines, the Mariana Islands, Malaysia and Indonesia (Randall and Lim, 2000; Sadovy and Cornish, 2000; Myers and Donaldson, 2003), South-Eastern and Western Australia (Kuiter, 1993), and the southern coastal waters of Jeju Island, South Korea (present study). Its absence in the Persian Gulf is puzzling (Heemstra and Randall, 1993).

\section{Remarks}

Epinephelus lanceolatus differs from other species of the genus by having tubules on lateral-line scales with four to six radiating branches. Except for large adults of E. malabaricus, E. itajara, and E. coioides (which have a few anterior lateralline scales with branched tubules and posterior lateral-line scales with a single tubule), the lateral-line scales of other Epinephelus have unbranched tubules (Randall and Heemstra, 1991). E. lanceolatus is closely related to E. itajara; both grow to enormous size and have a similar body shape, small eye, wide interorbital area, numerous platelets on the gill arches, short dorsal-fin spines, similar fin counts, and anterior lateral-line scales with branched tubules. However, E. lanceolatus differs from E. itajara in having cycloid scales (whereas E. itajara has ctenoid scales) on the sides of the body, and adults are vaguely mottled dark brown, the fins have numerous small black spots (whereas E. itajara have small black spots on the head and dorsal part of the body) (Heemstra and Randall, 1993, 1999). E. lanceolatus has been listed as a vulnerable species by the International Union for Conservation of Nature and Natual Resources (2012) since the mid-1980s (Shuk Man and Chuen, 2006), and this fish should be protected elsewhere. More research is needed with regard to the appearance of E. lanceolatus on the Southern coast of Korea.

\section{References}

Bloch ME. 1790. Naturgeschichte der ausländischen Fische. Schlesinger, Berlin, DE.

Cuvier $\mathrm{G}$ and Valenciennes A. 1828. Histoire naturelle des poisons. Tome second. Livre Troisième. Des poisons de la famille des perches, ou des percoïdes F. G. Levrault, Paris, FR.

Eschmeyer WN, Fricke R, Fong JD and Polack DA. 2010. Marine fish diversity: history of knowledge and discovery (Pisces). Zootaxa 2525, 19-50.

Fowler HW. 1907. Notes on Serranidae. Proc Acad Nat Sci Philad 59, 249-269. 
Günter A. 1869. Notice of a gigantic species of Batrachus from the Seycehelle islands. Ann Mag Nat Hist 3, 131-132.

Han SH, Kim BJ, Kim HJ, Lee SK and Ahn JH. 2011. National List of Species of Korea: Vertebrates. National Institute of Biological Resources, Incheon, KR, pp. 95-97 (in Korean).

Heemstra PC and Randall JE. 1986. Family No 166: Serranidae. In: Smiths' Sea Fishes. Smith MM and Heemstra PC, eds. SpringerVerlag, Berlin, DE, pp. 509-539.

Heemstra PC and Randall JE. 1993. Groupers of the World (Family Serranidae, Subfamily Epinephelinae): An Annotated and Illustrated Catalogue of the Grouper, Rockcod, Hind, Coral Grouper and Lyretail Species Knows to Date. FAO Species Catalogue. Vol. 16. Food and Agriculture Organization of the United Nations, Rome, IT.

Heemstra PC and Randall JE. 1999. Family Serranidae . In: The Living Marine Resources of the Western Central Pacific. FAO Species Identification Guide for Fisheries Purpose. Carpenter KE \& Niem $\mathrm{TH}$, eds. Food and Agriculture Organization of the Inited Nations, Rome, IT, pp. 2442-2548.

International Union for Conservation of Nature and Natural Resources (IUCN). 2012. 2012 IUCN Red List of Threatened Species [Internet]. IUCN, Cambridge, GB, Accessed 1 Oct 2012, http://www. iucnredlist.org.

Katayama M. 1984. Family Serranidae. In: The Fishes of the Japanese Archipelago. Masuda H, Amaoka K, Araga C, Uyeno T and Yo- shino T, eds. Tokai University Press, Tokyo, JP, pp. 126-138.

Konishi H and Nakabo T. 2007. Color Guide to the Japanese Fishes for Sport Fishermen. Enterbrain, Inc., Tokyo, JP (in Japanese).

Kuiter RH. 1993. Coastal Fishes of South-Eastern Australia. University of Hawaii Press, Honolulu.

Myers RF and Donaldson TJ. 2003. The fishes of the Mariana Islands. Micronesica, 35-36, 594-648.

Nakabo T. 2000. Fishes of Japan with Pictorial Keys to the Species. 2nd. Tokai University Press,Hadano, JP (in Japanese).

Ramsay EP. 1880. Description of a new species of Oligorus. Proc Linn Soc N S W, 5, 93-95.

Randall JE and Heemstra PC. 1991. Revision of Indo-Pacific groupers (Perciformes: Serranidae: Epinephelinae), with descriptions of five new species. Indo-Pac Fishes, 20, 1-332.

Randall JE and Lim KKP. 2000. A checklist of the fishes of the South China Sea. Raffles Bull ZooI Suppl 8, 569-667.

Sadovy Y and Cornish AS. 2000. Reef fishes of Hong Kong. Hong Kong University Press, Hong Kong, HK.

Shuk Man C and Chuen NW. 2006. Epinephelus lanceolatus [Internet]. IUCN Red List of Threatened Species, Version 2012. 1, Cambridge, GB, Accessed 4 Apr 2012, http://www.iucnredlist.org.

WoRMS. 2012. Epinephelus. In: Bailly N. FishBase. [Internet]. World Register of Marine Species, Accessed 4 Apr 2012, http://www.marinespecies.org/aphia.php?p=taxdetails\&id $=126068$. 